\title{
THE ROLE AND STATUS OF THE INDEPENDENT ELECTORAL COMMISSION
}

\author{
Mogopodi H Lekorwe
}

\author{
Dr Mogopodi Lekorwe is a senior lecturer and Director of \\ The Centre of Specialisation in Public Administration and Management \\ (CESPAM). \\ P / Bag 00705, Gaborone, Botswana \\ Tel: +267 355 2739; Mobile: +267 1312942 \\ e-mail: LEKORWEM@mopipi.ub.bw
}

\begin{abstract}
Free, fair and transparent elections are fundamental to democracy. Citizens need to be assured that the politicians truly reflect the will of the people. The bodies charged with overseeing the election process must be impartial and independent, transparent and accountable. Botswana's Independent Electoral Commission (IEC) has overseen two elections since its formation in 1997 and overall has been judged to have carried out its duties competently and fairly. The elections have been free of disputes, contributing to the widely held belief that Botswana is a stable democracy. The IEC is to be applauded for undertaking self-evaluations with stakeholders following each election in order to improve its performance.

However, the structure and funding of the IEC leave it open to the charge that it is not truly independent of government and this has led to allegations, particularly by the opposition, that it may be biased. These perceived threats to independence should be addressed in the interests of transparency and to reassure the voters and avoid messy contestation of election results. It is recommended that the IEC should be responsible to Parliament and not to the Office of the President. It should be adequately funded to enable it to perform its tasks and obligations under the Constitution and the Act. The chief executive officer of the IEC should be appointed by the IEC itself in order to guarantee loyalty.
\end{abstract}




\section{INTRODUCTION}

Electoral systems are considered to be the primary vehicle for choice and representational governance, which is the foundation of democracy. The system must provide opportunities for citizens, including the disadvantaged, to participate and influence government policy and practice. Effective management of electoral systems requires institutions that are inclusive, sustainable, just and independent and have electoral management bodies (EMBs) with the legitimacy to enforce rules and assure fairness and the cooperation of all stakeholders, including citizens and political parties (Lopez-Pinto, 2000). EMBs are therefore important institutions for building democracy, dealing directly with the organisation of multiparty elections and indirectly with governance and the rule of law.

This paper examines the role and status of Botswana's Independent Electoral Commission (IEC). It is divided into four sections. First, it defines EMBs and their role in democratic society. This is important as it puts the reader in a better position to understand the structure and functioning of the IEC. Second, it examines the different models of election management bodies used internationally. Third, it discusses the evolution of Botswana's IEC with the emphasis on the role and status of the institution. The fourth section draws some conclusions.

\section{ELECTION MANAGEMENT BODIES}

The importance of establishing an independent electoral management body is corroborated by the failure of several African countries to attain democracy in the initial stages of their independence. Experience shows that had a legal independent body managed the elections, the outcome might have been accepted by all those who contested. Consequently, as Barkan (1997) argues, the absence of an independent EMB caused harm.

However, it should be noted that elections cannot be seen as the only test of a democratic society. Experience around the world has shown that the holding of elections does not guarantee that a country will necessarily pass the democracy test. It is the interaction during the interval between elections between the people and those who come to power that can more precisely define the nature and character of democracy in a particular country.

Election management became more complex in the 1980s and 1990s when more and more countries entered the wave of democratisation and held multiparty elections. A well-managed election depends on the quality of the election management body. This view was confirmed by T S Seshan, a former chief election commissioner in India, who argued that a good election requires four elements: 
an election law that is fully tuned to provide free and fair elections, an election commission which is truly autonomous and fearless, administrative procedures that ensure that even the least privileged men and women can exercise their franchise freely without fear, and an electorate which is fully aware of its rights and responsibilities.

Although it is true that no two countries can have exactly the same type of EMB, some generalisations can be made. Firstly, EMBs can be classified according to the way in which they are interpreted and practise. Secondly, conducting an election in any country requires certain standard and fixed functions which are applicable to all countries, irrespective of the kind of structure in place. Thirdly, there is a growing trend in democratic countries to establish an independent multiparty electoral commission which is enshrined in the constitution. The complex skills needed to conduct elections require the establishment of an institution that is responsible for activities related to elections. These bodies are known by different names in different countries and the term election management body has been coined to refer to the body or bodies responsible for the management of elections in a particular country. An EMB is therefore a body established for the purpose of, and is legally responsible for, managing some elements which promote direct democracy. These may include, but are not limited to, referendums, citizens' initiatives, and recall votes. In general, EMBs have certain essential functions. They:

- determine who is eligible to vote;

- receive and validate the nomination of participants;

- register political parties and candidates;

- conduct voter registration;

- procure election material;

- promote public awareness of electoral matters by conducting civic education and information programmes particularly among women, youth, the illiterate, and disadvantaged minorities;

- conduct balloting;

- count votes;

- total the votes from polling locations;

- resolve electoral disputes;

- enforce the electoral law;

- train electoral officers.

A body with no direct responsibility for the essential elements of elections, for example, a boundary delimitation commission which exist solely for that purpose, is not regarded as an EMB. 
The work of an EMB is guided by certain principles. Klein (1995), Harris (1997), and Dundas $(1993 ; 1998)$ summarise these as:

- inclusiveness - obtaining support from all parties involved;

- transparency at all stages of the electoral process;

- accountability before the legislature and the public;

- responsiveness to the public need for voter information and civic education;

- a cost effective approach to management.

\section{MODELS OF ELECTION MANAGEMENT BODIES}

Election management is a broad concept involving the administrative infrastructure required to support the democratic process of elections. Elections are costly events and their success requires adequate preparation and planning. Elections also include a variety of tasks involving many people. ${ }^{1}$

Election management involves selecting the right system for the particular circumstances. There are a variety of models of election management systems the choice of a particular model depends on the history and culture of the country concerned, the political situation and educational standards of the people, financial resources, and the level and sophistication of the country's administration. Some of the factors which influence the nature and character of the EMB include the following: a tradition of constitutionalism, a willingness by leaders to negotiate during the transition period, the scope of the economy, and the extent of mass protest (Diamond, Linz \& Lipset 1988; Bratton \& Van de Walle 1997).

Election management is a service that normally attracts attention at the time of elections but is usually ignored during the intervals between them, a factor which can be costly. It is imperative that those involved in managing election, that is, political parties, civic groups and the legislature, work together to ensure continuous improvement of the process. This need for continuous improvement justifies the establishment of a permanent organisation as opposed to one that is put together at the time of an election.

A comprehensive study conducted by Professor Rafael Lopez-Pintor and commissioned by the United Nations Development Programme (UNDP) in countries which held elections regularly identified five models of EMBs. The first is an electoral commission that is independent of the executive and has full responsibility for conducting and managing elections. This form of body is common to new democracies and has deep traditions in Latin America.

The material used here is drawn from http: / / www.aceproject.dd. 
The second model is one where the government manages elections with the assistance of an oversight body composed of judges and members of the legal profession, political party representatives, or a mixture of both. This, also known as the French model, has regulatory, supervisory and judicial functions and is largely used in continental Western and European countries and former French African countries.

In the third model elections are managed entirely by the government. This is the case in a sizeable number of countries in Western Europe, South Asia, the Pacific, Caribbean, the Middle East and some parts of Africa.

The fourth model, a variation on the first, consists of two different bodies, each of them independent of the executive and responsible for direction and management functions. One body is responsible for election administration while the other performs regulatory functions. Examples of this model are found in Botswana, Colombia, Chile, Mozambique and Peru.

The fifth model is found in countries which have a highly decentralised system with only limited coordination and supervision by a national authority which is either independent, governmental or from a professional association. Examples of countries using this model include Canada, the United States, Germany, Switzerland and the United Kingdom.

Although the models discussed above are used all over the world, in practice they can be reduced to three, based on structural characteristics which combine recruitment methods with functions performed (Klein 1995). The three broad models are independent, governmental and mixed. The majority of countries use what is commonly known as the independent election management body. The nature and character of these bodies are also influenced by the political and cultural traditions and the democratic evolution of a particular country.

As the democratic process swept across the African continent and the Southern Africa region in particular, there was a call for the reform of electoral institutions. Thus, as early as 1993, a Senior Policy Seminar on Strengthening Electoral Administrative in Africa held in Accra, Ghana, under the auspices of the African Association of Public Administration and Management (AAPAM) and the Canadian International Development Agency (CIDA) advocated a credible election management body with the following attributes:

- There should be a permanent, independent and credible electoral agency responsible for organising and conducting periodic free and fair election.

- The mandate of the electoral agency should be defined in the constitution and should include the method of conducting elections; voter and other education; constituency delimitation; registration of 
voters, parties and candidates; formulation of electoral policies and procedures; and settlement of disputes over electoral matters.

- The electoral agency should include a reasonable number of members who should be non-partisan, enjoy security of tenure, and be appointed by the head of state, subject to approval by Parliament.

- The agency should be adequately funded and be granted autonomy to establish its own accounting procedures and greater flexibility in procurement procedures than the government.

- There should be legal provision for the electoral authority to mobilise additional staff and other resources during the conduct of elections

AAPAM 1993

This statement influenced some of the reforms that took place in the establishment of election management bodies around the globe, including in many countries in the Southern African Development Community (SADC) region. We now turn to the election management body in Botswana.

\section{THE ESTABLISHMENT OF \\ THE INDEPENDENT ELECTORAL COMMISSION}

The fact that the 2004 election went off without any disruptions reinforced the country's record as one of the most stable, liberal, and effective democracies in Africa. The upholding of this reputation calls for a competent and trusted election management body which is acceptable to all stakeholders and can deliver free and fair elections.

As stated above, the Act gives details of the role of the IEC with respect to the electoral process. However, there are certain broad responsibilities carried out by some election management bodies which are not necessarily performed by the IEC. First, the IEC is not responsible for the delimitation of constituencies. Opinions differ as to whether it should be. One school of thought argues that the conduct of free and fair elections and the delimitation of constituency boundaries are interrelated and it makes sense for the IEC to be responsible for both. It is felt that the expertise gained in one area can be relevant to the other. The counter argument is that even though the two elements are interrelated they must be divorced from each other in order to avoid potential conflicts of interest if an electoral commission is also to be an implementing agency. Both arguments are valid, but each country must decide what is best for it, taking its own circumstances into account.

The second factor is responsibility for party registration. Because political parties are the most important element in the political process there is a very 
close relationship between them and the IEC. However, in terms of the Societies Act, the registration of political parties is carried out by the Registrar of Societies. The Act specifies that any person wishing to register a political party must apply in writing to the Registrar of Societies who may refuse to register the party if, in his interpretation, it appears that it may engage in unlawful activities or if he believes the constitution, or rules, are repugnant or inconsistent with any written law. The Act further provides for a grievance procedure which allows parties to appeal to the minister should registration be refused.

Thirdly, there is the question of resolution of electoral disputes. Here, too, there is a divergence of opinion about how much of the judicial responsibility should be given to the election management body. The IEC does not have the power to deal with electoral disputes as these are left to the judicial system of the country.

For a number of years, Botswana's elections were held under a less autonomous system, directed by the Office of the President (Lekorwe \& Tshosa 2005). After numerous complaints from opposition parties and following consultations between government and opposition parties, modest changes were introduced (Somolekae 1999; Somolekae \& Lekorwe 1999). An Office of the Supervisor of Elections was created and located in a separate building from the Office of the President. But this was simply a cosmetic change as the office continued to report to the Office of the President. Opposition parties continued to complain that there was an absence of independence. The reputation and stability of the country was seriously challenged, to the extent that, in 1989, opposition parties threatened to boycott elections. This threat was repeated prior to the 1994 elections by the opposition Botswana National Front (BNF), which questioned the impartiality of the then supervisor of elections, who was said to be a card carrying member of the Botswana Democratic party (BDP) and to have contested the primary elections for the Lobatse-Barolong constituency in 1984. Taking the boycott threats seriously, in 1995 the then President, Sir Ketumile Masire, announced some major electoral reforms, which included the establishment of the Independent Electoral Commission.

\section{ROLE AND FUNCTIONS OF THE IEC}

The IEC came into being in June 1998 after the 1997 national referendum on electoral reforms. The referendum was held in order to solicit people's views on three envisaged reforms: the lowering of the voting age from 21 to 18; whether to allow Batswana who were resident outside the country to vote; and whether to set up an Independent Electoral Commission to run both local and national elections. 
In 1997 Parliament passed the Constitutional (Amendment) Act 18/1997, which repealed s 66 of the Constitution and introduced a new section, 65A, establishing the IEC as an autonomous and non-partisan institution. In terms of $\mathrm{s}$ $65 \mathrm{~A}$ the duties of the IEC include, among others: the conduct and supervision of elections of elected members of the National Assembly and members of a local authority, and conduct of a referendum; giving instructions and directions to the secretary of the commission appointed under s 66, in regard to the exercise of his or her functions under the election law: ensuring that elections are conducted efficiently, properly and freely. On completion of an election the commission must submit a report to the Minister of Presidential Affairs and Public Administration, who, in turn, must submit the report to the National Assembly at its first meeting.

The same section prescribes the composition of the commission: a total of seven members. It is headed by a chairperson and deputy, who are a judge of the High Court and a legal practitioner respectively. The two are appointed directly by the Judicial Service Commission (JSC). The remaining five commissioners are appointed by the JSC on the recommendation of the All Party Conference for a period of two successive terms of Parliaments, that is, ten years.

The criteria for appointment as a commissioner include the following: a commissioner may not have been declared insolvent or bankrupt under any law and may not have been convicted of any offence involving dishonesty in any country (s 65a subs 6). The secretariat of the commission is headed by the secretary, who is appointed by the president in terms of s 66(2) and whose main responsibilities are to exercise general supervision over the registration of voters and over the conduct of elections. The specific detail of the functions of the secretary of the commission are found in $\mathrm{s} 3$ of the Electoral Act (cap 02:07), which stipulates the duties as follows:

- To exercise general direction and supervision over the registration of voters.

- To exercise general direction and supervision over the administrative conduct of elections and enforce on the part of all election officers fairness, impartiality and compliance with provisions of the Act.

- To issue to election officers and registration officers such instruction as he/ she may deem necessary to ensure effective execution of the provisions of the Act.

- To exercise and perform all other powers and duties conferred and imposed upon him/her by the Act.

The secretary, like the members of the commission, must be a citizen of Botswana; must not have been declared insolvent or bankrupt; and must not have been convicted of any offence involving dishonesty in any country. 
The detailed criteria for both the commissioners and the executive officer recognise the importance of having an election management body conduct free and fair elections. In order to enhance the independence of the IEC secretary, the position has some constitutional protection. The secretary must vacate the office on attaining the age of 65 and can only be removed from office for the inability to perform the functions of the office.

One of the key functions of the IEC, as stipulated in the Constitution, is the registration of voters. Indeed, the concept of free and fair elections implies freedom of movement, speech, assembly and association; freedom from fear in connection with elections; and unimpeded candidate registration. Fairness includes a transparent electoral process, the absence of discrimination against political parties, and no obstacle to voter registration. Because the right to cast a vote depends on whether one is registered, great care and time must be invested in ensuring that the registration process proceeds smoothly.

Section 7 of the Electoral Act stipulates that the general registration of voters should commence after polling districts and polling stations have been established under s 5, or whenever the commission considers that it is necessary for new general rolls to be prepared. The commission must, by order published in the Government Gazette, declare a general registration period in respect of the constituency or constituencies specified in the order. In an effort to conduct free and fair elections, and also following the IEC commissioned study on voter apathy, the Act provides for continuous registration, or the updating of existing rolls every time there is a general election. Registration of voters other than during the general registration period is conducted at the office of the principal registration officer for each constituency. ${ }^{2}$

The IEC in Botswana performs somewhat similar functions to other election management bodies within the SADC region. However, one of the outstanding differences is that it is not responsible for the delimitation of constituencies. This role is performed by a delimitation commission. Section 64 of the Constitution empowers the Judicial Service Commission, which is headed by the chief justice of the High Court of Botswana, who is appointed by the president, to appoint a delimitation commission consisting of a chairman and not more than four other members, at intervals of not less than five years or more than 10 years. Section 64 (ss 2) gives clear guidelines as to when a delimitation commission can be appointed. These include: when Parliament has made provision for or passed a law altering the number of seats of elected members of the National Assembly and when a comprehensive national population census has been held.

2 For a detailed account, see Electoral Act cap 02:07 s 8. 
In carrying out its duties the delimitation commission must ensure that the boundaries of each constituency are such that the number of inhabitants is as nearly equal to the population quota as is reasonably practicable. ${ }^{3}$

Provided that the number of inhabitants of a constituency may be greater or less than the population quota in order to take account of natural community of interest, means of communication, geographical features, diversity of population, and the boundaries of Tribal Territories and administrative district.

Section 65(12)

The delimitation commission is chaired by a person who holds or has held high judicial office. Its membership excludes certain people, including members of the National Assembly and persons who are or have been within the preceding five years actively engaged in politics or are public officers. The last delimitation commission, which was appointed in 2002, was chaired by Justice Dibotelo. To ensure the impartiality and independence of the commission, the Constitution further states that

In their exercise of its functions under this section the Delimitation Commission shall not be subject to the direction or control of any other person or authority.

The sprit of this is confirmed by the fact that once the commission has submitted its report to the president it cannot be altered and the commission is dissolved on the date the report is delivered.

Thus, although the demarcation of constituencies can affect the outcome of an election, in Botswana this is not the responsibility of the election management body, which is the IEC. Clearly there can be no fair elections without a clear and balanced delimitation of boundaries. It is therefore in the interests of all that the boundaries are accepted by all stakeholders (Kabemba 2005). In the past, opposition parties have complained that the criteria tend to favour the ruling party in some constituencies, especially in its stronghold areas (Sechele 2004). ${ }^{4}$

\footnotetext{
3 A population quota means the number obtained by dividing the number of inhabitants of Botswana by the number of constituencies into which Botswana is divided under s 63 of the Constitution.

4 Evidence suggests that ruling party strongholds such as the Central District, Northeast and Kgalagadi gained most from subdivision into small constituencies.
} 


\section{PERFORMANCE OF THE IEC}

Since its establishment the IEC has conducted two elections - in 1999 and in 2004. Initially, concerns were raised about its effectiveness. One of the main concerns related to the accuracy of the voters' roll. The IEC's lack of preparation in this regard led to then President Festus Mogae declaring a state of emergency in order to restore the franchise of some 67000 voters who had registered during the supplementary registration process in 1999.

After the election the IEC organised a number of workshops in order to evaluate its performance - a process that is important for the growth and development of the commission as an institution as it continues to look at other matters within the electoral process with a view to suggesting improvements. Two such workshops were held in November and December of 1999, with two objectives:

- To assess critically the organisation and conduct of the election.

- To provide a forum for political parties, civil society, the media and other stake holders to make suggestion about possible improvements in future elections.

Somolekae \& Lekorwe 1999

The workshops were attended by political parties, civil society groups, the media and academics. The main purpose was to evaluate all aspects of the electoral process, including the registration process, logistical issues, the actual voting process, civic and voter education, the independence of the IEC and its relationship with the media and political parties; issues covering the core functions of the IEC.

I will not undertake in this paper a comprehensive evaluation of the IEC's performance but will highlight some of the key issues identified by the evaluators.

Voter registration is one of the critical aspects of any democratic election. Thus the performance of the IEC can be measured against its preparedness for the registration process. Voter registration is a complex process which includes, among other things, the recruitment, training and deployment of registration officers

One of the features of the 1999 elections was the low turnout of voters. This came as an eye opener to the IEC and showed there was a need to focus attention on voter education, which would, in turn, improve voter registration. As Somolekae \& Lekorwe (1999) point out, there was lack of planning with regard to the youth, who were voting for the first time.

Surprisingly, despite all the complaints, misgivings and mistrust about the IEC, the evaluations undertaken by organisations including the Democracy 
Research Project of the University of Botswana (DRP) overall rated its performance favourably, with more than 90 per cent finding the registration process easy. Thus, the conclusion reached was that the 1999 election went smoothly, considering it was the first to be conducted by the IEC. One of the recommendations of the 1999 evaluation was that the IEC should undertake research in order better to understand the root causes of voter apathy.

An evaluation of the 2004 election was also undertaken with the intention of helping the IEC identify its strengths and weaknesses in order to prepare for the 2009 election. The objectives of the 2004 evaluation workshops were not fundamentally different from those of the previous ones, though there was interest in determining the progress made in relation to recommendations made in 1999.

There was no doubt that the IEC had taken solid steps to ensure that there was a marked improvement in the management of the election. Acting on the recommendations emanating from the 1999 evaluation the IEC commissioned the DRP to conduct a voter apathy study. One of the recommendations emerging from the study was that voter education should be intensified before the 2004 election. Indeed, the evaluation of the 2004 election acknowledged that the IEC had embarked on a very aggressive civic and voter education programme (Sebudubudu \& Lekorwe 2005). As in 1999 the IEC was favourably rated as having conducted a free and fair election.

\section{THE STATUS OF THE IEC}

Although to date the IEC has not posed any serious threat to the stability of the country's democracy, a number of issues have been raised, which, if not attended to, may pose a threat in the future. One of the contentious issues that have been vehemently challenged by the opposition parties is the composition of the commission. Section 65a deals with this aspect, but does not go further to detail clearly the procedure to be followed by the All Party Conference when shortlisting candidates.

The All Party Conference is a meeting of all registered political parties in Botswana which is convened from time to time at the pleasure of the Minister of Presidential Affairs and Public Administration in the Office of the President. Thus the lack of clarity as to who can become a commissioner has the effect of eroding the public's confidence in the system. The selection of the current commissioners was riddled with controversy. Opposition parties were dissatisfied with the process to the extent that they boycotted the meeting. Only two opposition parties, with insignificant membership, joined the BDP to nominate members of the IEC. The result is that the major opposition parties question the legitimacy of the present members of the IEC. With reference to the nomination of the commissioners, a 
member of the public commented that 'such an act is a drawback in democratic dispensation. Botswana Labour Party and MELS are minnows that cannot claim to represent the interests of opposition parties' (Mmegi, 2 August 2004).

In the same vein, dismissing the significance of the commission, a senior member of an opposition party argued that the party is not bothered by the IEC as the institution does not take major decisions of concern to opposition parties, such as party funding.

In a democracy all parties must have an equal chance of being heard and participating in the electoral process. The IEC is crucial to successful election administration and to building and maintaining public confidence in the process. In view of the fact that the decisions and policies implemented by the commission may have an impact on women's participation in elections the election management body should include women as full participants. This not only guarantees gender balance but may help to ensure that women's perspectives are taken into account. Currently, neither the Constitution nor the IEC Act addresses the issue of gender balance, an omission which can seriously undermine the credibility of the institution. The IEC should, if necessary, consider special training for women to ensure that they are qualified to assume positions on the commission as a way of addressing the imbalance that exists at present.

Another serious point of contention raised by opposition parties is the appointment of the secretary to the commission. According to s 66(1) the secretary is appointed by the president without reference to any other person or independent authority. The result is that there are no checks and balances. In the absence of these checks and balances, there is a high possibility that the officer may owe allegiance to the appointing authority, and this goes against the principle of independence.

Related to this is the independence of the IEC as an institution. This is not guaranteed either by the Constitution or by the Act. The relationship of the IEC to the government, especially the Office of the President, has led many to doubt its independence. For example, the IEC relies on government for its resources, including transport, finance and staff. The staff of the IEC is governed by the same conditions that apply to the public service. Although one cannot suggest that the executive directs the IEC to carry out its functions in a particular way, its independence is compromised even by perceptions which may not necessarily be true.

The IEC has, on several occasions, declared that it is independent and enjoys some legitimacy. Indeed, one of the commissioners has argued that 'there is no interference whatsoever by the government in the operations of the IEC, even though the state finances the commission' (Tsie 2003, p 147). However, it is believed that this independence would be enhanced if it had the power to set the election 
date - at present the date is set by the president who, as an interested party, may make a decision based on the preparedness of his or her party.

The president is expected to consult with the IEC about its preparedness for the election date, but does not have to divulge the date. As Dundas et al (2004) contend the IEC and other stakeholders were left in the dark about the election date in 2004. Taking into account previous elections, as well as careful reading of the Constitution, it was expected that the election would be held in mid-October. In the event, it was set for 30 October.

Based on the timing of previous elections, the SADC Parliamentary Forum also organised its activities with the mid-October date in mind. The later date, therefore, meant it was not able to reschedule. The secrecy surrounding the date affected many stakeholders, including international and regional networks. It adversely affected the budgets of political parties, mainly the opposition parties, which were experiencing financial difficulties and hence had to look for extra resources to sustain their campaigns.

Furthermore, the organisation of an election is a major undertaking which requires considerable financial resources. Under the current practice the IEC has no financial independence as it, like any other department, receives funding from government through the Ministry of Presidential Affairs and Public Administration. It submits its funding proposal through the Ministry of Finance and Development Planning which has the power to cut the budget proposal, especially if it does not support some of the commission's projects, for example, voter education, which may be considered a threat to government (Dundas et al 2004).

The resolution of election related conflicts is an important element in ensuring free and fair elections and stability in a democracy. The IEC in Botswana, unlike its counterparts in some countries, has no jurisdiction to deal with such conflicts. According to s 114 of the Electoral Act, all election related conflicts are dealt with by the High Court. ${ }^{5}$ Botswana has not had an election dispute which has threatened the security and stability of the country, such as was the case in Lesotho, for example, in 1998 (Sebudubudu 2005). The country has a well-established judicial system which can handle such disputes without delay - an essential element because an election dispute that is not handled expeditiously defeats the whole purpose.

In previous years, the High Court has handled a number of cases, mainly instituted by opposition parties, in which cheating has been alleged. A number of these were dismissed on technicalities but in the case of two parliamentary elections - Gaborone South in 1984 and Mochudi in 1989 - the results were

For a detailed account of the petition procedures, see Electoral Act Part X. 
declared null and void. In 2004 the ruling party threatened to challenge the outcome of the Gaborone Central constituency election but did not proceed with the case. Among the reasons advanced for the withdrawal were that the challenger had already been nominated to Parliament and appointed to the Cabinet.

It is important to note that no system is perfect and, as successful as the IEC may have been, it must constantly strive to improve its performance. Electoral reforms are therefore inevitable in this information age. The credibility of the election management body is essential to the holding of free and fair elections and transparency is essential to credibility.

Transparency can be facilitated by all stakeholders playing an active part and appreciating the role and functions of the commission. The confidence that is bestowed by members of the public on the IEC may be measured by the number of people who participate in the election, the level of accountability of politicians to voters, and the manner in which the commission renders its service to the public.

\section{CHALLENGES}

Elections are necessary to sustain democracy. It is particularly important that the electorate perceives them as free and fair. It is therefore important that the institution performing this role is trusted. Although there is general acceptance of the IEC in Botswana as an election management body, there are still challenges that need to be addressed. As discussed above, these include, among others, the status of the IEC, the appointment of the secretary of the IEC, the independence of the IEC. These are discussed briefly in turn.

\section{Status}

The status and mandate of the IEC continue to be a hotly contested issue in Botswana. As mentioned above, an effective IEC should be responsible for all matters related to elections and not just the staging of a poll on election day. Currently the IEC is not responsible for delimitation and it is believed that it should be given that responsibility.

\section{Appointment of the secretary}

An EMB should not only be impartial but must be seen by the public to be so. Members of the body must be appointed in such a way as to ensure the confidence of the public and the political parties alike (Dundas 1997). The present arrangement, by which the secretary of the IEC is appointed by the president, goes against the spirit and intent of a transparent and neutral body. Political 
parties, as the main stakeholders, continue to question this method and argue that the secretary should be appointed by the commission in order to ensure that he or she is accountable to it.

\section{Independence}

Opposition parties in Botswana continue to complain about the lack of independence of the commission. Questions about the autonomy of the IEC have to do with the fact that it falls under the Ministry of Presidential Affairs and Public Administration instead of reporting directly to Parliament. The IEC does not have the power to recruit, deploy, and discipline its staff. This is done through the normal public service channels.

It does not have complete independence over the administration of its funds. It is important that the IEC should be adequately funded and be given the opportunity to manage the funds cost-effectively. This view is supported by Dundas (1997, p 210) when he argues that in budgetary matters the EMB should not 'become subservient, or under the control of the executive which is providing it with its funds and which could make pliability a prerequisite for adequate funding'.

\section{CONCLUSION}

Democracies throughout the world have established institutional structures, models and processes to ensure free, fair and transparent elections. However, even in the most advanced countries problems may arise. An example is the first US presidential election won by George Bush in relation to which there were and remain strong suspicions that the Florida election process was flawed.

So, the processes and institutions are not fool proof. In Botswana the IEC, which was established in 1998, has overseen two elections. In general the consensus is that it has performed relatively well. A positive move is the IEC's consultation with stakeholders after an election and its continuous self-evaluation and improvement of its performance.

There is, however, a perception, particularly among the opposition parties, that the IEC is not truly independent because of its links with government. Whether these links bias the IEC and introduce irregularities into the electoral process is a moot point. However, what is clear is that there is a perceived problem of bias and absence of transparency. It is important that these perceptions be corrected to assure the electorate of a free and fair election.

Accordingly, the IEC should have independent funding and not, as it is at present, be treated like a normal government department. The secretary of the 
commission should be appointed directly by the commission. The commission should report directly to Parliament, not to the Office of the President. The responsibility for setting the election date should be thoroughly discussed, as some feel this should be the task of the commission. Perhaps, instead, there should be a constitutional provision indicating more specifically when, in an election year, the election should be held and the time when the announcement should be made. The mandate of the IEC should be extended to include the delimitation of constituencies, because this is very much related to the election process.

\section{— REFERENCES}

Africa Association for Public Administration and Management. 1993. Report of the Senior Policy Seminar on Strengthening Electoral Administration in Africa. Accra, Ghana: AAPAM.

Barkan, Joel D. 1997. 'African Elections in Comparative Perspective'. In Elections: Perspectives on Establishing Democratic Practices. New York: United Nations Department for Development Support and Management Services (UNDDSMS).

Bratton, Michael \& Nicolas Van de Walle. 1997. Democratic Experiments in Africa: Regime Transitions in Comparative Perspective. Cambridge: Cambridge University Press.

Bratton, Michael. 1998. 'Second Elections in Africa'. Journal of Democracy 9(3).

Diamond, Larry, Juan J Linz \& Seymour Martin Lipset. 1988 (4 vols). Democracy in Developing Countries. Boulder, Colorado: Lynne Rienner.

Dundas, Carl W. 1993. Organising Free and Fair Elections at Cost-Effective Level. London: Commonwealth Secretariat.

(ed). 1997. Let's Talk about Elections. London: Commonwealth Secretariat.

- 1998. Compendium of Election Laws (2 vols). London: Commonwealth Secretariat.

Dundas, CW, Z Maundeni \& T Balule. 2004. 'Audit of the Independent Electoral Commission's Preparedness to Conduct Legitimate and Credible Elections in October 2004'.

Electoral Commission Report. 2000. Municipal Elections. Pretoria: Government Printer.

Garber, Larry. 1994. 'Election Commissions: Responsibilities and Composition'. Paper presented at the NDI-sponsored African Election Colloquium, Victoria Falls, Zimbabwe, November.

Government of Botswana. 1993. Electoral Act. Gaborone: Government Printer. .1997. Constitution (Amendment) Act, 1997. Gaborone: Government Printer. 
Harbeson, John W. 1998. 'Elections and Democratization in Post-Mengistu Ethopia'. In Krishna Kumar (ed). Postconflict Elections, Democratization, and International Assistance. Boulder, Colorado: Lynne Rienner.

Harris, Peter. 1997. 'An Electoral Administration: Who, What and Where'. Paper prepared at IDEA for the South Pacific Electoral Administrators' conference in Fiji, October.

—_ \& Ben Reilly (eds). 1998. Democracy and Deep-Rooted Conflicts: Options for Negotiators. Stockholm: International IDEA.

Independent Electoral Commission. 1999. Report to Vice-President and Minister of Presidential Affairs and Public Administration on the General Elections. Gaborone: Government Printer.

- 2002. Voter Apathy Report. Gaborone: Government Printer.

Kabemba, C K. 2005. The State of the Media in the Democratic Republic of Congo. EISA Occasional Paper.

Karume, S. 2005. Election Update - Tanzania No 2. Johannesburg: EISA.

Kiravu, R. 2005. Improving Elections in Tanzania. National Electoral Commission. Klein, Keith. 1995. 'Approaches to Conducting Elections: Why an Electoral Commission?' Paper prepared at IFES for presentation to the Constitutional Assembly of the Republic of South Africa. Cape Town.

Lekorwe, M \& O Tshosa. 2005. 'The Organisation of Elections and Institutional Reforms'. In Z Maundeni (ed). 40 years of Democracy in Botswana 1965-2005. Gaborone: Mmegi Publishing House.

Lodge, T, D Kadima \& D Pottie. 2002. Compendium of Elections in Southern Africa. Johannesburg: EISA.

Lopez-Pintor, R. 2000. Electoral Management Bodies as Institutions of Governance. New York: UNDP.

Matlosa, K. 2003. Survey of Electoral Systems and Reform Imperatives in the SADC Region. EISA Occasional paper No12. Johannesburg: EISA.

Molomo, G M \& G Somolekae. Sustainable Democracy in Botswana. International IDEA Archive http:/ / www.archive.idea.int/ideas.

Otlhogile, B. 1993. 'Judicial Intervention in the Election Process: Botswana's Experience'. In B Otlhogile \& P Molutsi (eds). Consolidating Democracy: The Electoral Process Under Scrutiny. Report of the Workshop on Electoral Law and Administration of Elections in Botswana. Gaborone, 19-20 May. DRP. 'Principles for Election-Management, monitoring and observations in the SADC Region' (PEMMO). 2003. Electoral Handbook No 13.

Report of the Delimitation Commission. Gaborone: Government Printer.

Report of the Electoral Commission of the Republic of South Africa (1999) National and Provincial Elections.

Scallan, A. 1997. 'Electoral Management' http: / / www.aceproject.dd.lfes.org/main 
Sebudubudu, D. 2005. 'Transparency and Settling Disputes in the Botswana Electoral System'. In Z Maundeni (ed). 40 years of Democracy in Botswana 1965 - 2005. Gaborone: Mmegi Publishing House.

_ \& M Lekorwe. 2005. An Evaluation of the 2004 Elections: Proceedings of Workshops held to Evaluate the 2004 Elections. Compiled for the Independent Electoral Commission.

Sechele, S. 2004. Election Update - Botswana. EISA No 2.

Somolekae, G. 1999. An Evaluation of the Performance of the Independent Electoral Commission (IEC) in Botswana's 1999 Elections. Report prepared on behalf of the Democracy Research Project, UB.

_ \& M Lekorwe. 2000. An Evaluation of the 1999 Elections. Independent Electoral Commission.

Tsie, B. 2003. 'The Role, Functions and Performance of Botswana's Independent Electoral Commission'. Journal of African Elections 2(1). 